\title{
The Rising Tide of Outreach and Engagement in State and Land-Grant Universities in the United States: What are the Implications for University Continuing Education Units in Canada?
}

\author{
Scott McLean, University of Calgary \\ Gordon Thompson, University of Saskatchewan \\ Peter Jonker, University of Saskatchewan
}

The authors would like to acknowledge the support and advice of colleagues from the University of Saskatchewan Extension Division. This paper was initially presented at a session at the 2005 CAUCE conference in St. John's. The authors would like to thank participants to that session for their comments and questions.

\begin{abstract}
In this paper, we describe the outreach and engagement movement in the United States and explore the implications of this movement for university continuing education units in Canada. Across the United States, major universities have adopted the vocabulary of "outreach and engagement" to foster a shift in the relationships of those
\end{abstract} \begin{tabular}{l}
\multicolumn{1}{c}{ RÉSUMÉ } \\
Dans cette communication, nous \\
décrivons le mouvement de sen- \\
sibilisation et d'implication aux \\
États-Unis, et nous explorons les \\
répercussions de ce mouvement \\
pour les unités d'éducation per- \\
manente universitaire au Canada. \\
Partout aux États-Unis, les uni- \\
versités principales ont adopté un \\
vocabulaire relié à la sensibilisation
\end{tabular}

Canadian Journal of University Continuing Education

Vol. 32, No. 1, Spring 2006

pp. 83-108 
universities with communities and organizations beyond the traditional boundaries of the institution. This vocabulary has its roots in the work of Ernest Boyer (1990, 1996) and the Kellogg Commission on the Future of State and Land-Grant Universities $(1999,2000)$. In the past decade, many American universities have adopted new leadership and organizational structures to make an operational commitment to outreach and engagement. In Canada, university continuing education units have traditionally been involved in activities that fit within the concept of outreach and engagement, and leaders of such units should consider the implications of the outreach and engagement movement. et l'implication pour favoriser un changement de paradigme dans les relations de ces universités avec les communautés et organisations qui va au-delà des limites traditionnelles de l'institution. Ce vocabulaire est tiré de l'œuvre de Ernest Boyer $(1990,1996)$ et de la Kellogg Commission on the Future of State and Land-Grant Universities (1999, 2000). Au cours des dix dernières années, beaucoup d'universités américaines ont adopté de nouvelles structures de leadership et d'organisation pour concrétiser un engagement opérationnel envers la sensibilisation et l'implication. Au Canada, les unités d'éducation permanente universitaire s'étaient traditionnellement impliquées dans des activités faisant partie du concept de sensibilisation et $\mathrm{d}$ 'implication, et les leaders des unités semblables devraient considérer les répercussions du mouvement vers la sensibilisation et l'implication.

\section{INTRODUCTION}

Although outreach is a term with a long heritage in higher education, the notion of engagement has only recently taken on a distinctive meaning in the university context. At the level of individual faculty members, engaged scholarship is widely associated with the work of Ernest Boyer. In Scholarship Reconsidered, Boyer (1990) defined the "scholarship of application" as the processes through which knowledge is mobilized to resolve practical challenges or social problems. In an article published posthumously, Boyer (1996) replaced the term "application" with that of "engagement." Engaged scholarship requires moving beyond the "noblesse oblige" model of university experts providing service to communities to a truly collaborative model in

Revue canadienne de l'éducation permanente universitaire

Vol. 32, No 1, primtemps 2006 
which faculty members and others learn together through mutually defining issues, take action to address those issues, and reflect on the outcomes of such action (Rice, 2002, pp. 13-14).

While Boyer was reconsidering the nature of scholarly work, the Kellogg Commission on the Future of State and Land-Grant Universities mobilized the presidents or chancellors of 24 major American universities to reconsider the future of publicly funded higher education. The Kellogg Commission's publications (e.g., 1999; 2000) have been seminal to the concept of the engaged institution. The commission's work was rooted in a widespread sense of malaise among state and land-grant universities. The commission (1999) summarized the need for change in the following terms:

One challenge we face is growing public frustration with what is seen to be our unresponsiveness. At the root of the criticism is a perception that we are out of touch and out of date. Another part of the issue is that although society has problems, our institutions have "disciplines." In the end, what these complaints add up to is a perception that, despite the resources and expertise available on our campuses, our institutions are not well organized to bring them to bear on local problems in a coherent way.

Meanwhile, a number of other issues present themselves. They include enrollment pressures in many Western and Southwestern states; longterm financial constraints and demands for affordability and cost-containment; a growing emphasis on accountability and productivity from trustees, legislators and donors; and urgent requests from policymakers for solutions to national and international problems of all kinds. (p. 9)

In light of such pressures and criticisms, the Kellogg Commission (2000) exhorted state and land-grant universities to adopt institutional engagement as a primary means to "renew the covenant" between the universities and the American people.

The notions of engagement associated with Boyer and the Kellogg Commission resonate strongly with university continuing education (UCE) in Canada. At the level of individual UCE practitioners, much scholarly and professional practice has been undertaken within three historical paradigms. These paradigms are expressed in Rogers's (1993) insightful review of the evolution of agricultural extension and adult education. In the "transfer of knowledge" paradigm, knowledge is created through scientific research and transferred to relatively passive target populations by the training and intervention of field workers. The "meeting needs" paradigm focuses on meeting the needs of the target population, rather than satisfying the scientific agenda of the researcher. In this paradigm, the identification of problems, issues, and priorities emerges from needs-assessment processes; change 
agents and trainers act as informants and interpreters in these processes. Although the creation of new knowledge is responsive to the needs of target populations, the application and dissemination of that knowledge is still quite directive. As in the first paradigm, the second paradigm presumes that target populations cannot meet their needs without sustained expert intervention. In the third paradigm, the "developing independent learners" paradigm, researchers and change agents recognize that target populations are actively engaged with issues and problems and, ultimately, are responsible for their resolution. The role of researchers and change agents is to share, in a reciprocal manner, knowledge and resources that will empower target populations to become even more effective and self-reliant. In contrast to the transferring knowledge and meeting needs paradigms, the notion of developing communities of learners requires an approach to scholarship parallel to that described by Boyer as "engaged."

At the institutional level, UCE in Canada faces a search for meaning comparable to that sparking the work of the Kellogg Commission. As is the case with state and land-grant universities in the United States, UCE units in Canada face numerous challenges and pressures from various stakeholders, including those associated with institutional restructuring, financial restraint, and growing expectations for revenue generation and responsive programming. At heart, however, and in a manner comparable to the roots of the Kellogg Commission, is a larger uncertainty, a sense that the relationship between UCE and the broader society is no longer what it could and should be.

On the one hand, these are exciting and promising times for UCE. The assertion that it is a key component of individual growth and societal development is common to many classic authors in the field (e.g., Brookfield, 1986; Houle, 1973; Knowles, 1970). In recent decades, the contention that lifelong learning is a prerequisite for individuals and societies to prosper in a rapidly changing world has become increasingly popular. International organizations such as UNESCO (Delors et al., 1996), the OECD (1996), the European Commission (2001), and the G8 Summit (1999) have published normative exhortations about the importance of lifelong learning in the contemporary world. Human Resources Development Canada (2002) has asserted:

To remain competitive and keep up with the accelerating pace of technological change, Canada must continuously renew and upgrade the skills of its workforce. We can no longer assume that the skills acquired in youth will carry workers through their active lives. Rather, the working life of most adults must be a period of continuous learning. (p. 37)

From this point of view, continuing education is an integral means through which individuals and nations may adapt to globalization, new information and communication technologies, the emergence of knowledge-based economies, and associated social and cultural changes.

Revue canadienne de l'éducation permanente universitaire

Vol. 32, No 1, primtemps 2006 
On the other hand, it is a period in which UCE is seen to have abandoned its commitment to serving social justice through educational programming (Archer \& Wright, 1999; Collins, 1991; Cram \& Morrison, 2005; Cruikshank, 1991, 1998, 2001; Einsiedel, Jr., 1998; Selman, 2005; Thompson \& Lamble, 2000; Welton, 1987). Some authors have claimed that UCE in Canada was historically the site of social activism by educators struggling for community development and justice. In the contemporary period, however, it is seen to have lost its social activist role. Haughey (1998) captured the sense of pride in the past:

I was struck by the passion, creativity, and dedication of those adult educators of the 1930s, 1940s, and 1950s in particular, as they struggled to promote social justice and change in Canada. Many of those men and women were from extension departments. In their time, they accepted the challenge of helping to develop an informed citizenry capable of understanding and countering the oppressive social and economic conditions of their day. (p. 200)

From this point of view, UCE was once a vibrant and democratic means through which activists and citizens worked to create a better world. However, for a range of reasons, including the pressures of globalization and institutional cost-recovery mandates, it no longer fulfills its potential as an active force for social change. Comparable claims have been made regarding the abdication of civic responsibility by land-grant universities in the United States (Alperovitz \& Howard, 2005; Checkoway, 2001).

In this paper, we describe the concept of outreach and engagement and examine how seven American universities have taken steps to make this concept operational. We conclude by exploring the implications of the outreach and engagement movement for UCE units in Canada. Our overarching concern is the future role of continuing education, and continuing education units, at Canadian universities. As both Archer and Wright (1999) and Selman (2005) observed, UCE has passed through several distinct eras in Canada and appears poised to enter another, as of yet uncertain, phase of development. Using conceptual background and case-study research on the outreach and engagement model and its implementation, we hope to foster further reflection and discussion of the opportunities and challenges that this model presents for the future of UCE in Canada. 


\section{WHAT Is "OUTREACH AND ENGAGEMENT"?}

It is relatively easy to define "outreach" by contrasting it with "intramural work." Intramural work can be understood as those aspects of teaching, research, and service that take place on campus and primarily involve members of universities' internal communities: faculty members, degree-credit students, administrators, and staff. Outreach refers to scholarly and professional practices that involve individuals, organizations, or communities outside the traditional boundaries of the university. Outreach can be understood as a distinct subset of university activities in the areas of teaching, research, and service.

Although easy enough to define, identifying which forms of scholarly and professional practice constitute "outreach" and which constitute "intramural" is a challenge. Table 1 presents a typology of faculty practices, organized according to the traditional categories of teaching, research, and service. In each category, it is possible to work in ways that are largely intramural and in ways that involve outreach. The table identifies the broad categories of faculty practice that may be considered "outreach" teaching, research, and service. It is important to note that outreach and intramural work are not mutually exclusive. For example, community-based research projects may result in publications for disciplinary-based, peer-reviewed journals, while on-campus instruction for degree-credit students may result in the development of high-quality workshops that can be used with off-campus professional audiences.

Table 1 presents a simplified means to understand the conceptual distinction between outreach and intramural work; it does not effectively represent the integration of faculty members' practices. Ideally, faculty members' teaching, research, and service work is integrated such that the various cells of Table 1 may be involved in the same project. Table 1 also does not recognize the numerous contributions to university outreach made by nonacademic staff. Their contributions are important, both in support of academic activities and as independent means of connecting the university with its external communities.

In simple terms, engagement refers to a new way of thinking about the relationship of the university with the communities it serves. The following passage comes from the Kellogg Commission (1999):

It is time to go beyond outreach and service to what the Kellogg Commission now defines as "engagement." By engagement, we refer to redesigned teaching, research, and extension and service functions that are sympathetically and productively involved with the communities universities serve, however community is defined.

Revue canadienne de l'éducation permanente universitaire

Vol. 32, No 1, primtemps 2006 
The Rising Tide of Outreach and Engagement ...

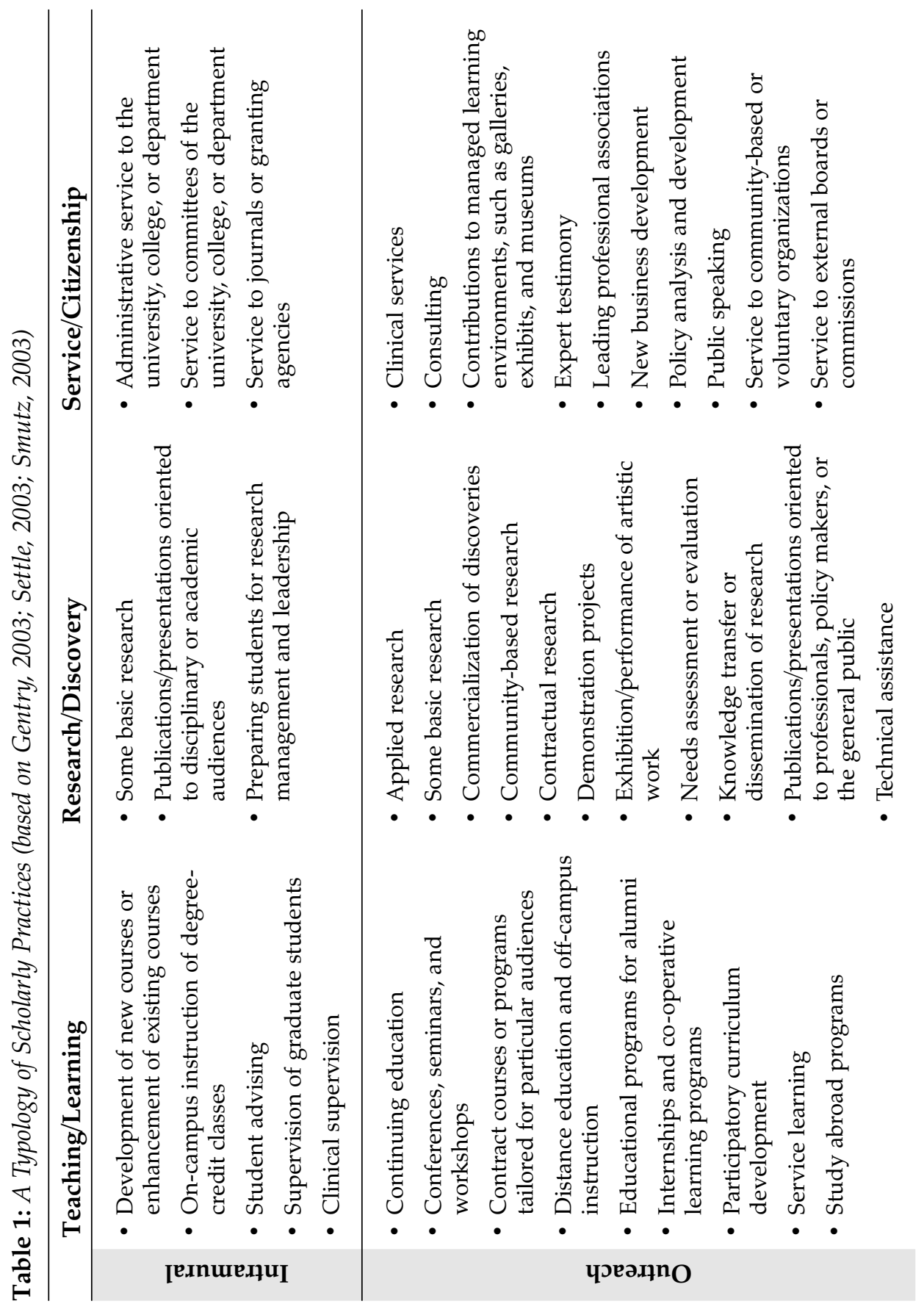

Canadian Journal of University Continuing Education

Vol. 32, No. 1, Spring 2006 
This commission defines engagement as something that goes well beyond Cooperative Extension and conventional outreach. It even goes beyond most conceptions of public service. Our inherited ideas emphasize a one-way process of transferring knowledge and technology from the university (as the source of expertise) to its key constituents. The engagement ideal is profoundly different; embedded in it is a commitment to sharing and reciprocity. By engagement the Commission envisions partnerships, two-way streets defined by mutual respect among the partners for what each brings to the table.

Such partnerships are likely to be characterized by problems defined together, goals and agendas that are shared in common, definitions of success that are meaningful to both university and community and developed together, and some pooling or leveraging of university and public and private funds. The collaboration arising out of this process is likely to be mutually beneficial and to build the capacity and competence of all parties. (p. 27)

In essence, engaged institutions have two key characteristics. First, a significant portion of the university's teaching, research, and service activities is meaningfully oriented toward the priorities, aspirations, and needs of the communities it serves. Second, the university, through the diverse activities of its faculty, staff, and students, is involved in a broad range of collaborative and mutually beneficial relationships with individuals, organizations, and communities external to the university.

Fundamentally, engagement is both a philosophical principle and a practical mode of working. Both outreach and intramural work can be undertaken with high levels of engagement. Indeed, a continuum of engagement is possible. At one end of the continuum (rarely, if ever, empirically observed), a completely non-engaged approach to scholarly and professional practice would involve solipsistic professors, living within their own mental worlds and undertaking work of no interest or value to others. At the other end, a completely engaged approach to scholarly and professional practice would involve the regular interaction of members of the university community and those of its external communities so that the university's teaching, research, and service activities were profoundly related to its external communities' priorities.

If outreach is a distinct set of scholarly and professional practices, and engagement is a combination of philosophical principles and modes of working, what is "outreach and engagement"? Outreach and engagement refers to new forms of understanding and of practising the work that connects universities with the outside world. The phrase implies not only the establishment of mutually beneficial partnerships between the university and exter-

Revue canadienne de l'éducation permanente universitaire

Vol. 32, No 1, primtemps 2006 
nal communities, but also the integration of teaching and research practices with service to society. It is important to note that outreach and engagement is not something different from teaching, research, and service; rather, it is a distinctive approach to undertaking and integrating teaching, research, and service. Outreach and engagement encompasses the university's administrative practices in areas such as student services, industry liaison, and university advancement, and, as such, it is the responsibility of faculty, students, staff, alumni, and other members of the university community.

An engagement continuum combined with the previous typology of outreach and intramural work results in a three-dimensional model of outreach and engagement. As Figure 1 illustrates, teaching, research, and service may be practised in either intramural or outreach mode. In both modes, relatively more or less engagement with external communities is possible.

Although outreach and engagement has been implemented using a number of models, its fundamental premise is to better integrate a university's research and teaching mandates with its external communities and stakeholders. This model shifts traditional practices in extension and public service to focus on making the university's core activities more relevant to the broader community.

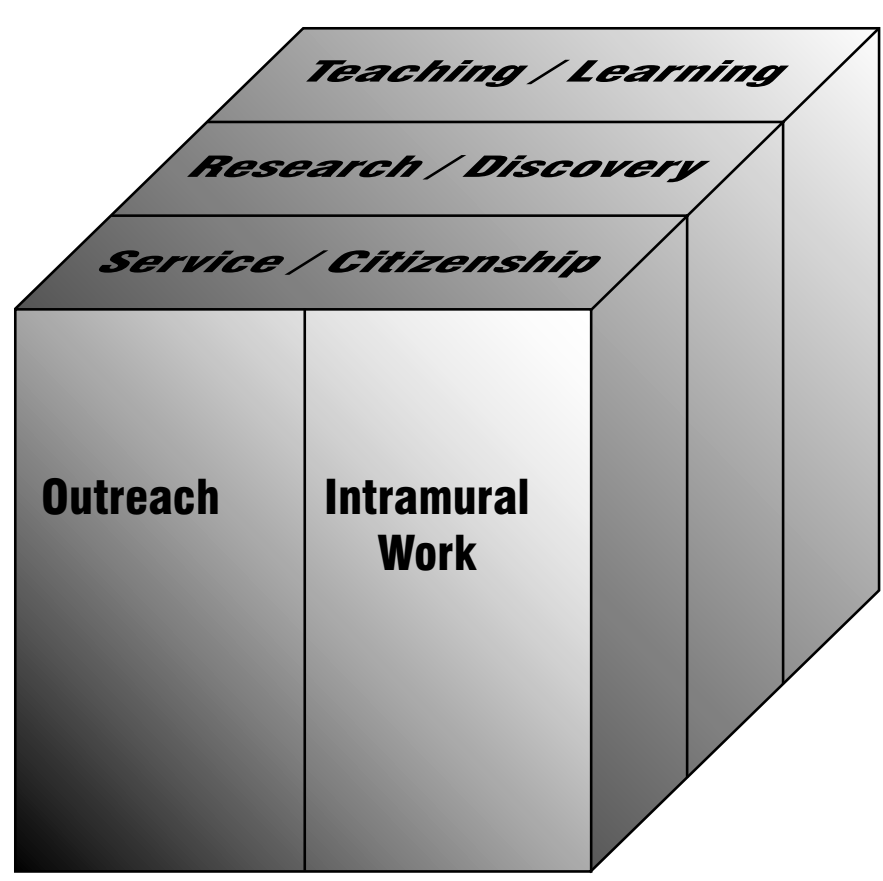

More Engaged

Figure 1: The Outreach and Engagement Cube

Canadian Journal of University Continuing Education

Vol. 32, No. 1, Spring 2006 
The notion of the engaged university has enjoyed considerable attention across North America in the past decade. Following from the work of the Kellogg Commission, the American Association of State Colleges and Universities (AASCU) organized a Task Force on Public Engagement. The AASCU (2002) identified four key elements of the engagement process:

- build and strengthen the requisite relationships with partners

- work proactively with these partners to identify needs and opportunities for academic engagement

- encourage students and faculty to engage with community needs and reward such engagement

- increase awareness of partners regarding opportunities and resources available through the institution. (p. 11)

A growing literature describes institutional efforts to become engaged institutions: University of California (Timar, Ogawa, \& Orillion, 2004); University of Maryland at College Park (Alperovitz \& Howard, 2005; Wilson \& Simson, 2003); Michigan State University (Fear, Bawden, Rosaen, \& FosterFishman, 2002; Sandmann, Foster-Fishman, Lloyd, Rauhe, \& Rosaen, 2000; Simon, 1999); University of Nebraska at Omaha (Schumaker \& Woods, 2001); Ohio State University (Ray, 1999); Oklahoma State University (Keener, 1999); Penn State University (Alter \& Book, 2001; Ryan, 1998); University of South Florida (Finkelstein, 2001); University of Wisconsin, Extension (Wise, Retzlaff, \& Reilly, 2002); and University of Wisconsin, Parkside (Letven, Ostheimer, \& Statham, 2001).

To better understand the potential implications of outreach and engagement for UCE units in Canada, we decided to examine how the concept actually influenced institutional planning and behaviour. To do so, we undertook case studies of seven institutions in the United States.

\section{Methodology}

Case-study research was conducted into the manner in which seven American universities were implementing an outreach and engagement agenda. The following universities were selected as case studies: University of Illinois at Urbana-Champaign (UI-UC); Ohio State University (OSU); Michigan State University (MSU); North Carolina State University (NCSU); Pennsylvania State University (PSU); University of Toledo (UT); and University of Wisconsin (UW).

To select this sample, a list of universities reputed to be actively implementing an outreach and engagement agenda was developed. First on this list were the 24 universities that took part in the Kellogg Commission. Further networking with the National Association of State Universities and

Revue canadienne de l'éducation permanente universitaire

Vol. 32, No 1, primtemps 2006 
Land-Grant Colleges, supplemented by online research, added 10 more institutions to the initial list. Web explorations garnered basic statistics for each candidate institution and gave a sense of how far various universities had advanced in implementing their outreach and engagement agenda.

To reduce the list to seven universities, a balance of several variables was sought. Chosen first, and this variable was afforded the most weight, were those that had been attempting to implement an outreach and engagement agenda for a relatively longer period of time; second, were those comparable in size to our own institution, the University of Saskatchewan; third, were those with multiple campuses and hence relatively more layers of administration; and fourth, were those with government-subsidized co-operative extension units.

Clearly, the final sample of seven institutions was not systematically representative of American universities. This small sample was purposively chosen, rather than randomly selected, for its potential insight into the outreach and engagement movement, rather than to generalize findings to the overall population of American universities. Based on the sample selected, a set of questions was developed to use as a template, while case-study research used a combination of the review of existing documents, email contact, and telephone interviews with key informants.

\section{FINDINGS}

From the case studies, it was evident that, whereas the overall discourse around outreach and engagement was well established, animated, and forward looking, implementation agendas lagged considerably behind. Given that change in public universities is activated through collegial rather than top-down decision-making processes and thus occurs relatively slowly, this discrepancy was predictable.

It was also evident that these universities approached outreach and engagement in diverse ways, another expected result considering that each must, with a view to securing internal support for new strategic directions and concomitant organizational change, embrace as much as possible current structures within that change. As reflections of their individual institutional histories, current organizational structures inevitably have characteristics that are unique to each institution. Despite the individuality of each institution, the research findings, based on seven key questions that each institution had, to varying degrees, addressed to make its outreach and engagement work operational, are presented next.

Canadian Journal of University Continuing Education

Vol. 32, No. 1, Spring 2006 
1. How is outreach and engagement conceptualized within the mission of the institution?

In most cases, the universities had developed, or were developing, official statements outlining the meaning and importance of outreach and engagement to the institution. In their mission statements and/or other institutionwide strategic planning documents, most (UT, PSU, MSU, OSU, and NCSU) used language that echoed that of the Kellogg Commission (1999) and clearly configured engagement as infusing all three traditional university roles of teaching, research, and service. At MSU, for example:

Outreach is a form of scholarship that cuts across teaching, research, and service. It involves generating, transmitting, applying, and preserving knowledge for the direct benefit of external audiences in ways that are consistent with university and unit missions. [http://ntweb4.ais.msu. edu/default.asp]

In several cases, specific policy and/or institutional planning documents were developed to afford specific direction to implementing an engagement agenda. For example, PSU's report UniSCOPE 2000: A Multidimensional Model of Scholarship for the $21^{\text {st }}$ Century provided not only an inclusive definition of scholarship but also a clear and detailed conceptual framework informed by the engagement paradigm [http://www.outreach.psu.edu/News/Pubs/ uniscope.html]. One of six current strategic goals for PSU's Outreach and Cooperative Extension Unit is "Continue to develop a comprehensive organizational infrastructure that supports and enhances Penn State's capacity for academic engagement and outreach." UW was in the midst of an internal consultation process aimed toward articulating a policy on university engagement.

2. What leadership positions or agencies have been created?

In almost all cases studied, and early in their respective implementation processes, the universities established high-level leadership positions with campus-wide authority on outreach and engagement. The following positions were reported:

PSU VP, Outreach and Cooperative Extension, reporting to the president and leading the Office for Outreach and Cooperative Extension

MSU Assistant Provost, Outreach and Engagement, reporting to the Vice-Provost, Academic Affairs, and leading the Outreach and Engagement Office

OSU Vice-President, University Outreach, reporting to the president and leading the Office of University Outreach

Revue canadienne de l'éducation permanente universitaire

Vol. 32, No 1, primtemps 2006 
UW Chancellor, UW Extension (not a new position), reporting to the overall president of the multi-campus UW system and leading UW Extension, which embraces the Cooperative Extension, Continuing Education, and Distance Education units

NCSU Vice Chancellor, University Extension and Engagement, reporting to the chancellor and leading the Office of Extension and Engagement

UI-UC Vice Chancellor, Public Engagement and Institutional Relations, reporting to the chancellor and leading the Office of Public Engagement and Institutional Relations

3. What central organizational units have been established to catalyze, facilitate, support, and monitor outreach and engagement activities?

In almost all cases, as identified above, a new office or unit was established with institution-wide responsibilities for outreach and engagement. In some instances, these permanent units were preceded by temporary transitional structures that provided guidance and coordination to realizing outreach and engagement aims. For example, OSU established a President's Council on Outreach and Engagement in the late 1990s, which was followed in 2001 by the current Office of University Outreach; UT, which was still in the early stages of developing an engagement agenda, established an ad hoc Presidential Council on Outreach and Engagement in 2003, mandated to "study and recommend the needed and appropriate administrative structure and institutional infrastructure for advancing our engagement mission."

Typically, although the newly established unit and leader were positioned at a high administrative level, they were not given authority to exercise control over pre-existing units. Their effectiveness therefore was expected to flow mostly from their ability to motivate and persuade. At PSU, for instance, the key overarching vehicle was the Coordinating Council for Outreach and Cooperative Extension, consisting of representatives (mostly Deans) of colleges and other units, chaired by the VP, Outreach and Cooperative Extension, and serving as a discussion forum and advisory group. Likewise, the role of UI-UC's new Public Engagement and Institutional Relations Office appeared to consist entirely of bridging, nurturing synergies, and supporting integration among the five or more pre-existing campus extension and outreach units. Its vice chancellor did not convene a university-wide consultation committee, but instead used a senate committee to this end.

NCSU is atypical. Its organizational restructuring brought two extension units (Industrial Extension Service and Cooperative Extension Service), an economic development unit, and the McKimmon Centre for Extension

Canadian Journal of University Continuing Education

Vol. 32, No. 1, Spring 2006 
and Continuing Education (which includes non-credit distance education) together under the newly established Office of Extension and Engagement.

At UT, the University College had been the traditional home to various centralized extension units: Continuing Education, Workplace Credit, Organization Development and Leadership, and Economic and Community Development. The University College Dean has led the transition toward embracing and implementing an engagement paradigm; she indicated that a new and separate outreach and engagement unit is likely to be established, reporting to the provost and absorbing all existing extension functions.

4. What mechanisms have been established to coordinate or promote decentralized outreach and engagement activities?

In most cases, the universities provided some form of financial incentive for initiatives that fit the institution's outreach and engagement priorities, in the form of granting programs and revenue-sharing or partnership funds. A range of non-financial mechanisms had also been developed:

- Establishing interdisciplinary centres and institutes. Each of the centres/ institutes described above and not vested with authority over extension programs was mandated primarily to support other units that directly manage programs. Thus, MSU has the Outreach and Engagement Office; OSU, the Office of University Outreach; PSU, the Coordinating Council for Outreach and Cooperative Extension; UI-UC, the Public Engagement and Institutional Relations Office; and UT, the Council on Outreach and Engagement.

- Organizing periodic bus tours to take faculty and students out to communities. MSU invited select faculty and graduate students from across disciplines (up to 40 per trip) on state-wide tours, up to three days in length, for pre-arranged meetings with community representatives to promote and explore potential collaborations.

- Appointing Associate Deans, Outreach and Engagement. PSU's University Outreach Council consisted primarily of Associate Deans, Outreach, from all of the colleges and the VP and three Associate VPs, Outreach. Similarly, at UI-UC, both the Director, Office of Continuing Education, and Associate Dean, Agriculture, had formal or informal cross-appointments to the Public Engagement and Institutional Relations Office.

- Appointing outreach and engagement "fellows" or "scholars" (they hold tenure in an academic department, but have some relationship with the Outreach and Engagement Office). UI-UC does this. At OSU, five of 19 colleges have joint appointees, known as "Extension Specialists." 
5. How are faculty members encouraged and rewarded for taking part in engaged scholarship?

This issue defies easy change as standards for promotion and tenure are generally deeply rooted in research and teaching performance. In the words of an MSU respondent: "Those forms of O\&E that are types of teaching or research will be recognized; service forms of O\&E are less likely to be rewarded through tenure and promotion." In some cases, such as at NCSU, promotion and tenure standards were revised in order to promote more university-wide inclusion of outreach and engagement activities in teaching, research, and service. However, others, such as UW and OSU, only recognized outreach in their standards for Extension faculty.

In addition to the need for reform in this crucial area, several other forms of recognition have been developed:

- Grant programs for outreach and engagement. For example, OSU awards seed grants to support initiatives of community involvement via service learning; the O\&E Office of MSU partners with MSU Extension to administer a fund of approximately $\$ 400,000$ annually to support peer-reviewed applications for community-based research projects; UIUC's Public Engagement and Institutional Relations Office draws 2\% of gross revenue from its Office of Continuing Education and uses this discretionary pool of funds as seed money to support proposed new engagement initiatives.

- Special pools of "merit increases" available only for outreach and engagement work. UT, for example, was considering doing this.

- Awards or public recognition for exemplary outreach and engagement projects. All seven case-study universities reported one or more forms of this, which were implemented through university publications, public print and airwave media, and special award banquets.

- Monetary awards by way of revenue-sharing or fee-for-service agreements (PSU and OSU). Further, PSU was moving from a net-revenuesharing to a gross-revenue-sharing model "so that they [other departments] get ' $x$ ' percent of the money and our job is to control our costs."

6. How are outreach and engagement activities and accomplishments monitored and evaluated?

In several cases, a directory or database of outreach and engagement was maintained. Several universities (UI-UC, UW, OSU) kept a public engagement database; UI-UC and UW used a logic model to track outreach and engagement activities; UT was developing a campus-wide inventory of such activities; and MSU's Outreach and Engagement Office created an annual reporting form for faculty to record their activities in this area.

Canadian Journal of University Continuing Education

Vol. 32, No. 1, Spring 2006 
In some cases, pertinent activities and accomplishments were reported in the plans and annual reports of individual faculty members, departments, or colleges. Mostly, however, such internal reporting reached the public eye only through the institution's main annual report. For example, NCSU invited each unit representative to provide an outreach and engagement update at its monthly Extension Operations Council meeting and used these to publish an Annual Report of Accomplishments.

A consortium of the "Big Ten" universities launched an initiative to create a system for benchmarking and assessing engagement activities. On May 23 and 24, 2005, MSU hosted the Benchmarking University Engagement Conference, which aimed to build on this initiative [http://csue.msu.edu/confinfo.asp].

\section{ISSUES EMERGING FROM the Case Study Research}

Representatives of the seven American universities were invited to identify unresolved issues and challenges with respect to developing and implementing an engagement agenda at their respective institutions. The challenges they identified while being interviewed are summarized below.

\section{Funding}

Four of the university representatives drew attention to the issue of inadequate commitment of core funding to implementing an engagement agenda; core funding must be both sufficient and sustained. As one interviewee stated: "The current reduced levels of staffing, and forecast of further reductions in resources, make it seem more challenging to keep engagement as a high (and well-integrated) priority."

\section{Changing the Culture}

Three of the interviewees expressed frustration with the slow progress of changing the behaviour patterns of faculty to support increased engagement. Here are some of their observations:

There is little common understanding of what outreach and engagement entails; we need to conduct ongoing professional development activity and integrate O\&E definitions, principles and practices.

Without behavioural change on the part of many individuals, it is impossible to create an engaged institution. Paying attention to this human factor is essential.

Revue canadienne de l'éducation permanente universitaire

Vol. 32, No 1, primtemps 2006 
Although concepts like public scholarship are beginning to change the academic culture in ways that legitimize engagement, we clearly have a long way to go.

\section{Tension Between Research and Outreach Mandates}

Two interviewees noted that many faculty, especially research faculty, resist embracing an engagement agenda because they perceive engagement as intruding on their research agendas. This tension is entrenched, perhaps especially, in land-grant universities, as these have powerful and longestablished extension programs. It relates to a perception among some that buying in to the engagement paradigm is tantamount to selling out on academic freedom. One interviewee captured the tension this way: "Traditionally, scholarship has been viewed as private craft. Scholars are supposed to be detached and objective. There is concern that getting involved in civic life and dealing with public issues may threaten objectivity and hence scholarship."

\section{Cross-Disciplinary Integration}

Large universities tend to develop silos along disciplinary lines, and it is a challenge to bridge these. Nevertheless, since solutions to community-based problems are likely to span multiple disciplines, much better cross-disciplinary integration is required. One interviewee pointed to a need to "build strong cross-disciplinary/unit partnerships to implement engagement (there are always institutional barriers that make this difficult)." Likewise, the UI-UC representative reported that the university has not been successful, to date, in nurturing intercollegiate/interdisciplinary outreach and engagement centres of practice on campus, but would like to see this happen.

\section{Building Incentive and Reward Structures}

In the collegial culture of a university, success in implementing an outreach and engagement agenda may be most dependent on ability to motivate faculty. Several interviewees indicated that faculty need more and stronger incentives, including entrenchment of incentives in promotion and tenure processes. As two of them noted:

Unless engagement is appropriately recognized and rewarded, it will not become an integral feature of campus life.

We currently use the "distributed model" as there are no incentives for faculty to do their O\&E activities through the Office of Public Engagement and Institutional Relations; staff who do so, do so voluntarily, so individual motivation is paramount.

Canadian Journal of University Continuing Education

Vol. 32, No. 1, Spring 2006 


\section{IMPLICATIONS FOR UNIVERSITY CONTINUING EDUCATION UNITS IN CANAdA}

The Kellogg Commission (1999) developed a "seven-part test of engagement" (p. 45). In short, the engaged institution is (1) responsive to its communities, (2) respectful of its partners, (3) neutral in its contribution of academic resources to controversial issues, (4) accessible to all constituents, (5) characterized by an integration of research, teaching, and service missions, (6) able to coordinate its outreach and engagement efforts, and (7) characterized by strong resource partnerships with governments, business, and the non-profit sector. Will most Canadian universities take up the challenge of becoming truly "engaged" institutions and, if so, what are the implications for their university continuing education (UCE) units?

All universities in Canada are unlikely to make such a commitment. Nonetheless, there is a growing societal expectation in Canada for universities to become more engaged with the needs of their communities. Accordingly, it is reasonable to expect that some Canadian universities will make such a commitment and, among those that do, there will likely be differential consequences for their UCE units. A single prediction or prescription for CAUCE member-institutions is not offered here. Rather, it is hoped that the following observations will provide some insight into possible alternatives.

1. An outreach and engagement model is not adopted by the institution.

This is a business-as-usual outcome. In this event, the UCE unit would be likely to experience little change in its current operation. It would continue to be viewed by its host institution as revenue generating and to be confronted by competition from other units within the institution. Conceivably, the unit would be expected to contribute to some "window-dressing" efforts on the part of its institution to appear seriously engaged but this would be more for purposes of public relations. Wadsworth (1997) professed to be mystified that ". . . in most settings, 'public engagement' continues to resemble nothing more than traditional public relations." The "rhetoric versus reality" debate surrounding outreach and engagement requires further exploration and discussion. A number of authors have proposed that to become engaged, an institution must have strong and visible support from its president and have a centralized office and staff (AASCU, 2002; Hinck \& Brandell, 2000; Ryan, 1998; Walshok, 1999; Ward, 2003). In the absence of such inputs, no serious institutional commitment to outreach and engagement has been made.

Revue canadienne de l'éducation permanente universitaire

Vol. 32, No 1, primtemps 2006 
2. The institution adopts an outreach and engagement model, but the UCE unit is marginalized.

As the case studies revealed, this outcome has occurred in some American universities. In these instances, a separate "office of engagement" was created and the UCE unit was either ignored or saw its mandate shrink to little more than those revenue-generating activities not claimed by other units of the university. The Kellogg Commission (1999) report warned that the responsibility for "the engagement agenda" cannot just be left to the extension division, but, instead, must involve the whole institution (pp. 43-44).

Hopefully, however, a significant place is found for the extension/UCE unit in this agenda. Indeed, Ruiz de Molina (1996) argued:

The welfare of colleges and universities, and of our society in general, will depend upon building viable relationships with a wide range of audiences, and some of the greatest expertise in institutions of higher learning lies in continuing education professionals who have accrued over the years the talent of understanding criteria necessary for success in developing, implementing, and evaluating educational programs designed from the perspective of the outside constituent. (pp. 59-60)

In short, while responsibility for outreach and engagement should not be left solely to UCE units, it would be unfortunate if such units were not assigned a central role in the initiative.

3. The institution adopts an outreach and engagement model, and the UCE unit is expected to take on an expanded role without the needed resources.

Despite its shortcomings, this option provides an opportunity for UCE units and their members to stretch themselves professionally, develop new skills, and take on new responsibilities. For example, the coordination of servicelearning opportunities for students or the coordination of co-op and workplacement programs could be assigned to such units. The expertise that UCE professionals have developed in prior learning assessment and recognition (PLAR) is an obvious contribution they can make to assessing experiential learning opportunities. Moreover, university continuing educators have a great deal of experience not only with managing effectively with marginal resources but also with seeking out new sources of funding and support to achieve their objectives. Accordingly, while taking on more than can be managed effectively demands caution, this option may present a range of important opportunities. 
4. The institution adopts an outreach and engagement model, and the UCE unit is caught up in major institutional restructuring.

As noted in the case studies, American universities that have seriously adopted the engagement agenda have undertaken significant institutional reorganization to achieve this agenda. In many cases, this included the creation of a new position of institutional leadership, such as Vice-Provost, University Outreach. Such an individual is expected to provide a central leadership and coordinating function on behalf of the entire institution. Edelson (1995) asserted that this was likely to be the future of UCE and that the days of universities having a large, multipurpose continuing education unit were numbered. He predicted that more institutions would appoint someone " . . at the provostial or academic vice presidential level in the same sense that an institution may have coordination of undergraduate or graduate studies at the echelon" (p. 153). Moreover, he predicted that:

... smaller coordinative offices with limited permanent program commitments may, in fact, be the wave of the future in campus environments where there are many continuing education providers and there are no clear advantages to centralization to which all significant players can agree. (p. 154)

Such a new structure would need to coordinate UCE programs and services delivered by a number of different units within the organization. As noted earlier, an engaged institution is committed to a range of other activities and services, such as applied and community-based research, which also require coordination and leadership on an institutional level. Thus, it is conceivable that UCE units may be absorbed into a much larger organizational entity and, in the process, lose some of their identity and independence.

Which of these scenarios is most likely? We believe there is considerable room and opportunity for UCE units to play a leading role in the advancement and implementation of the outreach and engagement movement in Canada. Making outreach and engagement more than just rhetoric will require substantial expertise and energy, however. As the Kellogg Commission (1999) argued:

Making engagement real on our campuses will require broad strategies to identify community needs, catalogue community resources, highlight academic strengths and capacities, and coordinate the work of many individuals and groups, frequently over long periods of time. There are no quick fixes or painless solutions for many of the challenges our states and communities face. (p. 39)

Engagement, therefore, is about developing relationships with external communities such that those communities and the university benefit and

Revue canadienne de l'éducation permanente universitaire

Vol. 32, No 1, primtemps 2006 
develop a deeper understanding of their respective issues, concerns, and values. Many UCE units across Canada have the expertise and capacity to undertake the kind of sustained relationship building, program planning, and community development work that will be required to make outreach and engagement succeed. Our institutions, and the communities they serve, need this expertise and capacity to become truly engaged with one another. It may be overly optimistic, but it is possible to imagine a fifth scenario, in which the institution embraces an outreach and engagement model, and the UCE unit is provided the resources and the legitimacy to act as a catalyst for outreach and engagement on an institution-wide basis.

\section{CONCLUSIONS}

There is no doubt that outreach and engagement is an important movement in a number of major universities in the United States, although their approaches to outreach and engagement and the outcomes experienced from such approaches have varied. In this article, six key variables were identified, as were five central issues arising from the implementation of outreach and engagement in the seven case-study universities. Questions were posed and scenarios were presented that could provide the basis for informed debate about the adoption of outreach and engagement at Canadian universities.

Based on the study's findings, it was clear that the outreach and engagement model presents a complex set of opportunities and challenges for UCE units across Canada. Much of what such units currently do falls within the rubric of outreach and engagement as it has been conceptualized in the United States. Indeed, numerous articles and reports have recognized the experience, resources, and expertise that UCE practitioners in Canada can bring to the "engagement table" (Extension Committee on Organization and Policy, 2002; McDowell, 2004; Thompson \& Lamble, 2000; Walshok, 1999; Ward, 2003). Moreover, as noted by others (Archer \& Wright, 1999; Cram \& Morrison, 2005; Fear \& Sandmann, 1995; Garrison, 2001; Selman, 2005), a period of significant opportunity may be at hand for UCE units to provide the leadership needed for their host institutions to become truly "engaged." At the same time, as we have outlined, this opportunity is not without risks. The outreach and engagement movement provides a window of opportunity for UCE units to move away from the current situation in which they must compete with other institutional units and return to a situation in which they played a leadership role in facilitating their institution's coordinated engagement with community needs and aspirations.

Canadian Journal of University Continuing Education

Vol. 32, No. 1, Spring 2006 


\section{REFERENCES}

AASCU Task Force on Public Engagement. (2002). Stepping forward as stewards of place: A guide for leading public engagement at state colleges and universities. Washington, DC: American Association of State Colleges and Universities.

Alperovitz, G., \& Howard, T. (2005). The next wave: Building a university civic engagement service for the twenty-first century. Journal of Higher Education Outreach and Engagement, 10(2), 141-157.

Alter, T. R., \& Book, P. A. (2001). The engaged university: Reorganizing to serve the public good. Metropolitan Universities, 12(3), 30-40.

Archer, W., \& Wright, K. (1999). Back to the future: Adjusting university continuing education research to an emerging trend. Canadian Journal of University Continuing Education, 25(2), 61-83.

Boyer, E. (1996). The scholarship of engagement. Journal of Public Service and Outreach, 1(1), 11-20.

Boyer, E. (1990). Scholarship reconsidered: Priorities of the professoriate. Princeton, NJ: Carnegie Foundation for the Advancement of Learning.

Brookfield, S. (1986). Understanding and facilitating adult learning. San Francisco: Jossey-Bass.

Checkoway, B. (2001). Renewing the civic mission of the American research university. The Journal of Higher Education, 72(2), 125-147.

Collins, M. (1991). Adult education as vocation: A critical role for the adult educator. London: Routledge.

Cram, B., \& Morrison, D. (2005). University continuing education units: Agents for social change? Canadian Journal of University Continuing Education, 31(1), 29-50.

Cruikshank, J. (2001). Lifelong learning in the new economy: A great leap backwards. Canadian Journal of University Continuing Education, 27(2) 61-78.

Cruikshank, J. (1998). Are we aiding the enemy? Adult education in the global economy. Canadian Journal of University Continuing Education, 24(1), 101-113.

Cruikshank, J. (1991). University extension: How can we recapture the vision? Canadian Journal of University Continuing Education, 17(1) 21-37.

Revue canadienne de l'éducation permanente universitaire

Vol. 32, No 1, primtemps 2006 
Delors, J., et al. (1996). Learning: The treasure within. Paris: UNESCO Publishing.

Edelson, P. J. (1995). Historical and cultural perspectives on centralization/ decentralization in continuing education. Continuing Higher Education Review, 59(3), 143-156.

Einsiedel, A. A., Jr. (1998). Changes and emerging trends in the CE function on university campuses. Canadian Journal of University Continuing Education, 24(1), 9-14.

European Commission. (2001). Making a European area of lifelong learning a reality. Brussels: EU.

Extension Committee on Organization and Policy. (2002). The extension system: A vision for the $21^{\text {st }}$ century. Washington, DC: National Association of State Universities and Land-Grant Colleges.

Fear, F. A., Bawden, R. J., Rosaen, C. L., \& Foster-Fishman, P. G. (2002). A model of engaged learning: Frames of reference and scholarly underpinnings. Journal of Higher Education Outreach \& Engagement, 7(3), 55-67.

Fear, F. A., \& Sandmann, L. R. (1995). Unpacking the service category: Reconceptualizing university outreach for the $21^{\text {st }}$ century. Continuing Higher Education Review, 59(3), 110-122.

Finkelstein, M. A. (2001). Linking research and outreach: The center for engaged scholarship. Metropolitan Universities, 12(4), 99-106.

G8 Summit. (1999). The Cologne Charter: Aims and ambitions for lifelong learning. Retrieved June 18, 2005, from http://www.g8.utoronto.ca/summit/ $1999 \mathrm{koln} /$ charter.htm

Garrison, R. (2001). Leadership in continuing studies: The reflections of a dean. Canadian Journal of University Continuing Education, 27(1), 79-99.

Gentry, D. (2003). Purdue University: Engagement, the third mission. Paper presented at Outreach Scholarship 2003, May 12, 2003, Madison, Wisconsin.

Haughey, D. (1998). From passion to passivity: The decline of university extension for social change. In S. M. Scott, B. Spencer, \& A. M. Thomas (Eds.), Learning for life: Canadian readings in adult education (pp. 200-212). Toronto: Thompson Educational Publishing.

Hinck, S. S., \& Brandell, M. E. (2000). The relationship between institutional support and campus acceptance of academic service learning. The American Behavioral Scientist, 43(5), 868-881. 
Houle, C. (1973). The design of education. San Francisco: Jossey-Bass.

Human Resources Development Canada. (2002). Knowledge matters: Skills and learning for Canadians. Ottawa, ON: HRDC.

Kellogg Commission on the Future of State and Land-Grant Universities. (2000). Renewing the covenant: Learning, discovery, and engagement in a new age and different world. Washington, DC: National Association of State Universities and Land-Grant Colleges.

Kellogg Commission on the Future of State and Land-Grant Universities. (1999). Returning to our roots: The engaged institution. Washington, DC: National Association of State Universities and Land-Grant Colleges.

Keener, M. S. (1999). Strengthening institutional engagement: Addressing faculty issues to facilitate change. Journal of Higher Education Outreach $\mathcal{E}$ Engagement, 4(1), 29-36.

Knowles, M. (1970). The modern practice of adult education: Andragogy versus pedagogy. New York: Association Press.

Letven, E., Ostheimer, J., \& Statham, A. (2001). Institutionalizing universitycommunity engagement. Metropolitan Universities, 12(3), 63-75.

McDowell, G. (2004). Is extension an idea whose time has come- and gone? Journal of Extension, 42(6). Retreived April 30, 2006, from http://www.joe. org/joe/2004december/comm1.shtml.

OECD (Organisation for Economic Co-operation and Development). (1996). Lifelong learning for all. Paris: OECD.

Ray, E. J. (1999). Outreach, engagement will keep academia relevant to twentieth-century societies. Journal of Public Service E Outreach, 4(1), 21-27.

Rice, R. E. (2002). Beyond Scholarship Reconsidered: Toward an enlarged vision of the scholarly work of faculty members. New Directions for Teaching and Learning, 90, 7-17.

Rogers, A. (1993). Adult education and agricultural extension: Some comparisons. International Journal of Lifelong Education, 12(3), 165-176.

Ruiz de Molina, S. (1996). The role of continuing education in an era of academic accountability. Journal of Public Service E Outreach, 1(2), 58-63.

Ryan, J. H. (1998). Creating an outreach culture. Journal of Public Service $\mathcal{E}$ Outreach, 3(2), 27-34.

Sandmann, L. R., Foster-Fishman, P. G., Lloyd, J., Rauhe, W., \& Rosaen, C. (2000). Managing critical tensions: How to strengthen the scholarship component of outreach. Change, 32(1), 44-52.

Revue canadienne de l'éducation permanente universitaire

Vol. 32, No 1, primtemps 2006 
Schumaker, A., \& Woods, S. (2001). The role of a college in a university-wide approach to community partnerships: The University of Nebraska at Omaha experience. Metropolitan Universities, 12(4), 66-79.

Selman, G., Cooke, M., Selman, M., \& Dampier, P. (1998). The foundations of adult education in Canada. Toronto: Thompson.

Selman, M. (2005). An identity for Canadian university education. Canadian Journal of University Continuing Education, 31(1), 19-27.

Settle, T. (2003). Conceptualizing outreach at Virginia Tech. Paper presented at Outreach Scholarship 2003, May 12, 2003, Madison, Wisconsin.

Simon, L. A. (1999). Constructive and complex tensions in the art of engagement. Journal of Public Service \& Outreach, 4(2), 2-6.

Smutz, W. (2003). Integrating outreach (and engagement) into the university: A work in progress at Penn State. Paper presented at Outreach Scholarship 2003, May 12, 2003, Madison, Wisconsin.

Thompson, G., \& Lamble, W. (2000). Reconceptualizing university extension and public service. Canadian Journal of University Continuing Education, 26(1), 51-77.

Timar, T. B., Ogawa, R., \& Orillion, M. (2004). Expanding the University of California's outreach mission. The Review of Higher Education, 27(2), 187-209.

Wadsworth, D. (1997). Building a strategy for successful public engagement. Phi Delta Kappan, 78(10), 749-752.

Walshok, M. L. (1999). Strategies for building the infrastructure that supports the engaged campus. In R. G. Bringle, R. Games, \& E. A. Malloy (Eds.), Colleges and universities as citizens (pp. 74-95). Needham Heights, MA: Allyn \& Bacon.

Ward, K. (2003). Faculty service roles and the scholarship of engagement. ASHEERIC Higher Education Report. San Francisco: Jossey-Bass.

Welton, M. (Ed.). (1987). Knowledge for the people: The struggle for adult learning in English-speaking Canada, 1823-1973. Toronto: OISE Press.

Wilson, L. B., \& Simson, S. (2003). Combining lifelong learning with civic engagement: A university-based model. Gerontology \& Geriatrics Education, 24(1), 47-61. 
Wise, G., Retzlaff, D., \& Reilly, K. (2002). Adapting Scholarship Reconsidered and Scholarship Assessed to evaluate University of Wisconsin-extension outreach faculty for tenure and promotion. Journal of Public Service $\mathcal{E}$ Outreach, 7(3), 5-18.

\section{BIOGRAPHIES}

Scott McLean has a PhD in sociology from Carleton University. He is the director of continuing education at the University of Calgary and a professor of sociology. Scott served with the Extension Division at the University of Saskatchewan from 1994 through 2005.

Scott McLean détient un doctorat en sociologie de l'Université Carleton. Il est directeur de l'éducation permanente à l'Université de Calgary et professeur de sociologie. De 1994 à 2005, Scott a œuvré auprès de la Division de l'éducation permanente de l'Université de la Saskatchewan.

Gordon Thompson is the director of adult and continuing education programs with the Extension Division at the University of Saskatchewan. He has a PhD in adult and continuing education from the University of Wisconsin-Madison. He is a former president of CAUCE and was with the continuing education units at the universities of Manitoba and Victoria prior to joining the University of Saskatchewan.

Gordon Thompson est le directeur des programmes d'éducation permanente pour adultes à la Division de l'éducation permanente de l'Université de la Saskatchewan. Il détient un doctorat en éducation des adultes et permanente de l'Université du Wisconsin-Madison. Ancien président de l'AÉPUC, il a aussi fait partie des unités d'éducation permanente à l'Université du Manitoba et à l'Université de Victoria avant de se joindre à l'équipe de l'Université de la Saskatchewan.

Peter Jonker is an extension specialist at the University of Saskatchewan, where he is the director of environment, science, and technology programs. He completed a BA in literature and an MSc in wildlife and recreation from the University of Calgary and a certificate in adult continuing education.

Peter Jonker est spécialiste en éducation des adultes à l'Université de la Saskatchewan, où il occupe le poste de directeur des programmes de l'environnement, des sciences et de la technologie. Il a terminé un baccalauréat en littérature et une maîtrise en sciences de la faune et des loisirs à l'Université de Calgary, ainsi qu'un certificat en éducation permanente pour adultes.

Revue canadienne de l'éducation permanente universitaire

Vol. 32, No 1, primtemps 2006 